\title{
Influence of environmental settings on the prevalence of Trichodesmium spp. in the Bay of Bengal
}

\author{
Sahana Hegde, Arga Chandrashekar Anil*, Jagadish S. Patil, Smita Mitbavkar, \\ Venkat Krishnamurthy, Vissa V. Gopalakrishna
}

National Institute of Oceanography, Dona Paula, Goa 403 004, India

\begin{abstract}
Trichodesmium, an important marine nitrogen-fixing cyanobacteria, is widespread in tropical waters and contributes substantially to the global chemical cycles by new production. The interesting and intriguing feature of Trichodesmium blooms is the suddenness with which the blooms appear and disappear. A well-defined periodicity and annual rhythm of Trichodesmium blooms in the Indian south central coastal environments of the Arabian Sea between February and May is well documented. However, not much is known for the Bay of Bengal. Analysis of the surface water samples collected from the merchant vessels plying between Chennai and Singapore at regular intervals (February 2000 to September 2002) to study the variations in the micro-phytoplankton community indicated that Trichodesmium persists for a large part of the year in the south-eastern part of the Bay of Bengal. Remotely sensed images from 1997 to 2003 also indicated the prevalence of Trichodesmium in the south-eastern part of the Bay during the winter months and in the west (west Bay of Bengal and east Arabian Sea) during summer. This raises the possible role of physical forcing in the dispersal and seeding of Trichodesmium. The prevalence of stratified conditions in the Bay of Bengal almost throughout the year can be one of the causative factors facilitating the preponderance of Trichodesmium. The inter-annual variations observed indicate that the tracking of Trichodesmium will be useful in understanding the biogeochemistry of the region.
\end{abstract}

KEY WORDS: Indian Ocean $\cdot$ Cyanobacteria $\cdot$ Phytoplankton $\cdot$ Arabian Sea $\cdot$ Remote sensing

\section{INTRODUCTION}

The first description of Trichodesmium was by Captain Cook in the 1700s in Australian waters, and ever since, Trichodesmium has awed mariners and oceanographers with its large blooms which spread over hundreds of kilometres. Recently, Trichodesmium has been recognized as the most important marine nitrogen-fixing cyanobacteria (diazotrophs), with intriguing features such as nitrogen fixing in the presence of light without the formation of heterocysts (site of nitrogen fixation in other cyanobacteria). These diazotrophs contain proteinaceous vacuoles, or gas vesicles, providing cells with the necessary buoyancy to keep them near the surface (Capone \& Subramaniam 2005). They are widespread in tropical waters and are often the major component of the phytoplankton (Capone et al. 1997), thus making them an important contributor to the global chemical cycles by new production (Capone et al. 1997). Phytoplankton absorption could contribute to the seasonal warming of the surface waters of the Arabian Sea (Sathyendranath et al. 1991). Trichodesmium, being a major component of phytoplankton in the Arabian Sea, could make a significant contribution to the warming of the Arabian Sea. Warm waters, calm weather, low or no wind during several days, very low densities of other micro-organisms and highly transparent waters are among the conditions required for the formation of the blooms (Carpenter \& Price 1976, Capone et al. 1997). Since Trichodesmium can fix nitrogen, they are not nitrogen limited. Hence, it is suggested that their production may be limited by other 
elements such as iron and phosphorous (Karl et al. 1992, Rueter et al. 1992, Mulholland et al. 2002).

In the Indian Ocean Trichodesmium blooms have been recorded since 1942 (Devassy et al. 1978 and references therein). The first report of the blooms in the Arabian Sea was in 1972 (Ramamurthy et al. 1972), and their occurrence with a well-defined periodicity and annual rhythm between February and May has been described as a phenomenon (Devassy et al. 1978). The regular timing of the blooms suggests that physical factors such as stratification, winds and current patterns influence these blooms. In the Bay of Bengal, blooms have been observed since 1942 (Ramamurthy et al. 1972, Devassy et al. 1978 and references therein, Gomes et al. 2000, Jyothibabu et al. 2003). However, elucidation of spatial and temporal distribution was not attempted in any of the earlier investigations. In the present study, which is the first of its kind, surface samples were collected at regular intervals for a period of $3 \mathrm{yr}$. It was found that Trichodesmium spp. appear regularly during the fall and winter in the Bay of Bengal and make their presence felt during the summer months along the south west coast of India.

Remote sensing techniques provide an alternative solution for mapping Trichodesmium on a global scale. Algorithms to detect Trichodesmium from space have been developed by Borstad et al. (1992), Subramaniam et al. (2002) and Westberry et al. (2005). A sensitivity analysis on the potential for remote sensing of Trichodesmium (Tassan 1995) using a Sea-viewing Wide Field-of-view Sensor (SeaWiFS) concluded that it should be possible to distinguish this organism at concentrations as low as 0.1 to $0.3 \mathrm{mg}$ chlorophyll $\mathrm{m}^{-3}$. Therefore, to observe the large-scale temporal and spatial variations in the occurrence of Trichodesmium in the Northern Indian Ocean, remote sensing techniques were used. toms and dinoflagellates are presented elsewhere). Trichodesmium were counted as individual filaments, and if in a clump, they were standardized into smaller tufts (25 trichomes colony ${ }^{-1}$ ) and larger tufts (50 trichomes colony ${ }^{-1}$ ).

To identify probable Trichodesmium patches for the area bounded by $0^{\circ}$ to $20^{\circ} \mathrm{N}$ and $65^{\circ}$ to $104^{\circ} \mathrm{E}$, SeaWiFS Level 2 and Level 3 images were downloaded from http://oceancolor.gsfc.nasa.gov and SeaWiFS Data Analysis System (SeaDAS version 4.9.2). The Level 2 images 'L2_flags' tool in SeaDAS was used. Here, checks are made for different defined conditions, and when certain tests and conditions are met for a given pixel, a flag is set for that pixel for that condition. In this case, the condition indicated is Trichodesmium and the algorithm 'tricho' (http://oceancolor. gsfc.nasa.gov/DOCS/Ocean_Level-2_Data_Products.pdf) is specific to SeaWiFS (the code can be viewed at SeaDAS: General Questions, Topic: L2 Flags). The checks used to indicate the presence of Trichodesmium are areas of warm waters, low wind stress and water leaving radiances.

Images from SeaWiFS level 2 (merged local area coverage [MLAC] $1 \mathrm{~km}$ ) were studied for each month and the best swaths were used for the study region $\left(0^{\circ}\right.$ to $20^{\circ} \mathrm{N}$ and $65^{\circ}$ to $104^{\circ} \mathrm{E}$; Table 1 ). Since SeaWiFS Level 2 makes daily images available, we grouped individual swaths from $7 \mathrm{~d}$ as a week, i.e. 1 st -7 th as the first week of the month, 8th-14th as the second and so on and any one good image for that week was downloaded. This was carried out for all the weeks in the month. A minimum of 4 images of the area of interest were used for a month. However, there were some occasions on which good images were not available for some weeks in a month mostly due to distortion and cloud obstruction.

To display and mask SeaWiFS-L2 products with flags, a SeaWiFS Level 2 file was downloaded for the

\section{MATERIALS AND METHODS}

Under the Indian Expendable Bathythermograph (BT) programme, surface water samples were collected on 15 transects (14 to 21 samples collected at every longitude in each transect from February 2000 to September 2002) from merchant vessels crossing between Chennai and Singapore $\left(13^{\circ} 05^{\prime} \mathrm{N}\right.$, $80^{\circ} 29^{\prime} \mathrm{E}$ to $5^{\circ} 48^{\prime} \mathrm{N}, 96^{\circ} 12^{\prime} \mathrm{E}$ ) (Fig. 1). Surface water was collected with buckets. Diatoms, dinoflagellates and Trichodesmium spp. were enumerated and identified to the lowest possible taxonomic level (data regarding dia-

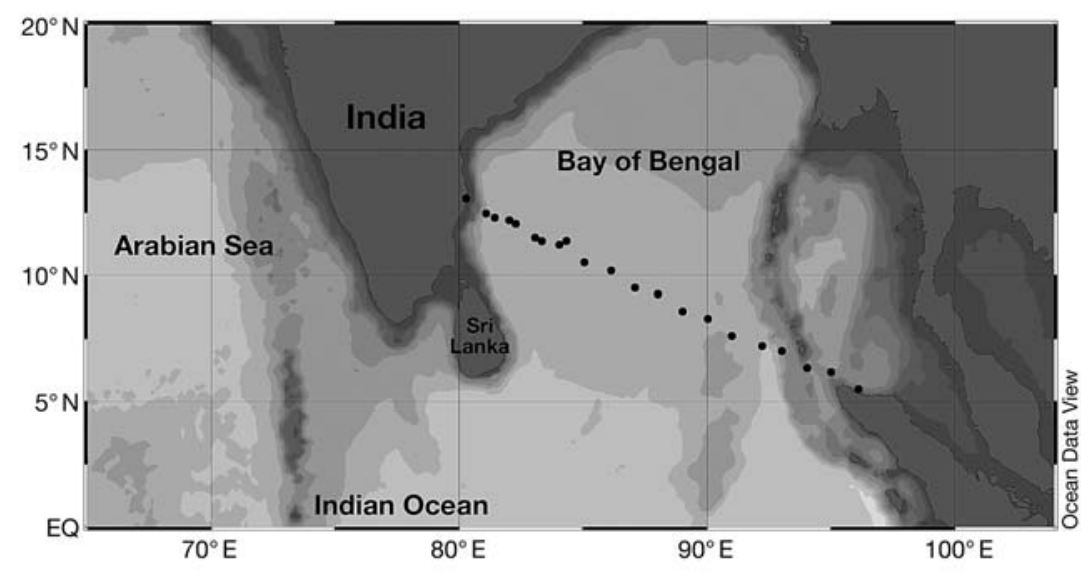

Fig. 1. Cruise track (samples were collected along the Chennai-Singapore shipping route with a $1^{\circ}$ interval between each station). EQ: equator 
Table 1. Total number of Sea-viewing Wide Field-of-view Sensor (SeaWiFS) images for the study region and number of images used for each month. Cloud obstructed and distorted images could not be used. Remaining images not used since they occurred in the same week as the ones used (only one good image used per week)

\begin{tabular}{|c|c|c|c|c|c|}
\hline Year & Month & Total & $\begin{array}{c}\text { Cloud } \\
\text { obstructed }\end{array}$ & Distorted & Used \\
\hline \multirow[t]{2}{*}{1997} & Nov & 43 & 15 & 21 & 2 \\
\hline & Dec & 46 & 7 & 31 & 4 \\
\hline \multirow[t]{7}{*}{1998} & Jan & 37 & 6 & 20 & 2 \\
\hline & Feb & 25 & & 21 & 4 \\
\hline & Mar & 35 & 2 & 24 & 2 \\
\hline & Apr & 35 & 4 & 18 & 2 \\
\hline & May & 35 & 4 & 12 & 2 \\
\hline & Nov & 41 & 4 & 31 & 4 \\
\hline & Dec & 39 & 4 & 17 & 4 \\
\hline \multirow[t]{7}{*}{1999} & Jan & 67 & 4 & 30 & 4 \\
\hline & Feb & 53 & & 33 & 4 \\
\hline & Mar & 62 & 3 & 37 & 4 \\
\hline & Apr & 61 & 9 & 47 & 3 \\
\hline & May & 65 & 21 & 38 & 3 \\
\hline & Nov & 46 & 6 & 14 & 4 \\
\hline & Dec & 61 & 12 & 18 & 3 \\
\hline \multirow[t]{7}{*}{2000} & Jan & 69 & 2 & 28 & 5 \\
\hline & Feb & 63 & 4 & 34 & 5 \\
\hline & Mar & 65 & 6 & 37 & 5 \\
\hline & Apr & 67 & 6 & 43 & 4 \\
\hline & May & 67 & 11 & 28 & 3 \\
\hline & Nov & 63 & 29 & 8 & 3 \\
\hline & Dec & 70 & 17 & 7 & 4 \\
\hline \multirow[t]{7}{*}{2001} & Jan & 66 & 22 & 8 & 4 \\
\hline & Feb & 62 & 16 & 9 & 4 \\
\hline & Mar & 70 & 14 & 25 & 3 \\
\hline & Apr & 66 & 12 & 33 & 3 \\
\hline & May & 70 & 31 & 23 & 3 \\
\hline & Nov & 62 & 12 & 24 & 4 \\
\hline & Dec & 69 & 6 & 26 & 4 \\
\hline \multirow[t]{7}{*}{2002} & Jan & 75 & 8 & 31 & 4 \\
\hline & Feb & 59 & 8 & 22 & 4 \\
\hline & Mar & 67 & 6 & 34 & 4 \\
\hline & Apr & 63 & 5 & 49 & 4 \\
\hline & May & 64 & 25 & 28 & 4 \\
\hline & Nov & 56 & 21 & 24 & 4 \\
\hline & Dec & 62 & 8 & 22 & 2 \\
\hline \multirow[t]{4}{*}{2003} & Jan & 58 & 18 & 16 & 4 \\
\hline & Feb & 59 & 3 & 20 & 4 \\
\hline & Mar & 70 & 8 & 27 & 4 \\
\hline & Apr & 68 & 9 & 34 & 4 \\
\hline
\end{tabular}

desired day and loaded onto SeaDAS. Subsequently, the chlorophyll and L2_flags products were selected. The L2 Flags Display from the Utilities menu is used to load and display probable Trichodesmium patches on the image. On the image window, the cursor was moved onto the points of Trichodesmium appearance marked on the image display, and the output for the location (Lat./Long.) was noted. These values were then superimposed on a map to represent a month-wise, qualitative presence of Trichodesmium (see Fig. 3: stars and circles indicate the months February to May and November to January respectively). Figs. A1-A12 in Appendix 1 (available online at: www.int-res-com/ articles/suppl/m356p093_app.pdf) contain the same values overlaid on images of monthly averages of chlorophyll from SeaWiFS level $3(9 \mathrm{~km})$ and monthly sea surface temperature (SST) averages from AVHRR (Advanced Very High Resolution Radiometer) Oceans Pathfinder Global $4 \mathrm{~km}$ Equal-Angle All SST V5 (NOAA) (http://podaac-www.jpl.nasa.gov).

Cloud cover and distorted images were major drawbacks for the region of interest, especially from June to August (Indian monsoons). Therefore, the data collated for the months November to May were used. This information was segregated into 2 sets, i.e. November to January (NDJ) and February to May (FMAM) based on the changes in the current patterns in the Bay of Bengal (Cutler \& Swallow 1984, Shetye et al. 1993, Tomczak \& Godfrey 2001). According to Carpenter et al. (1997) and Capone et al. (1998), Trichodesmium colonies are positively buoyant in the early mornings and, if wind stress is low, rise to the surface, but in the afternoon they become negatively buoyant and sink, and thus may not be detected by satellite. Taking this into consideration, all early morning swaths were used.

\section{RESULTS}

\section{In situ and remote sensing measurements}

Presence of high numbers of Trichodesmium was recorded on August 1, 2002 in 3 sampling stations off Chennai, i.e. at $12.83^{\circ} \mathrm{N}, 81.00^{\circ} \mathrm{E} ; 2.42^{\circ} \mathrm{N}, 82.00^{\circ} \mathrm{E}$; and $83.03^{\circ} \mathrm{N}, 11.98^{\circ} \mathrm{E}$ with approximately 330 trichomes $1^{-1}$ (Fig. 2). Satellite images were not available for the same day due to cloud cover; since Trichodesmium blooms last for a few days, we looked at cloud-free images around the date of observation, and an image for the August 4, 2002 showed Trichodesmium at $13.96^{\circ} \mathrm{N}, 80.38^{\circ} \mathrm{E}$. Trichodesmium was also recorded on October 19,2000 at $7.50^{\circ} \mathrm{N}, 92.02^{\circ} \mathrm{E}$ with $\sim 1800$ trichomes $l^{-1}$ (Fig. 2); there were no cloudfree remotely sensed images for the entire week but a swath on October 15, 2000 showed a Trichodesmium patch in the area $7.85^{\circ}$ to $8.17^{\circ} \mathrm{N}, 100.63^{\circ}$ to $100.81^{\circ} \mathrm{E}$. On August 18, 2002 in situ samples collected at $5.48^{\circ} \mathrm{N}, 97.40^{\circ} \mathrm{E}$ showed the presence of Trichodesmium ( 900 trichomes $\mathrm{l}^{-1}$; Fig. 2); remotely sensed values for the same day recorded Trichodesmium at $5.42^{\circ}$ to $5.30^{\circ} \mathrm{N}, 96.29^{\circ}$ to $96.57^{\circ} \mathrm{E}$, the remaining area was covered with clouds. As the 3 occurrences of high numbers of Trichodesmium matched positively with 


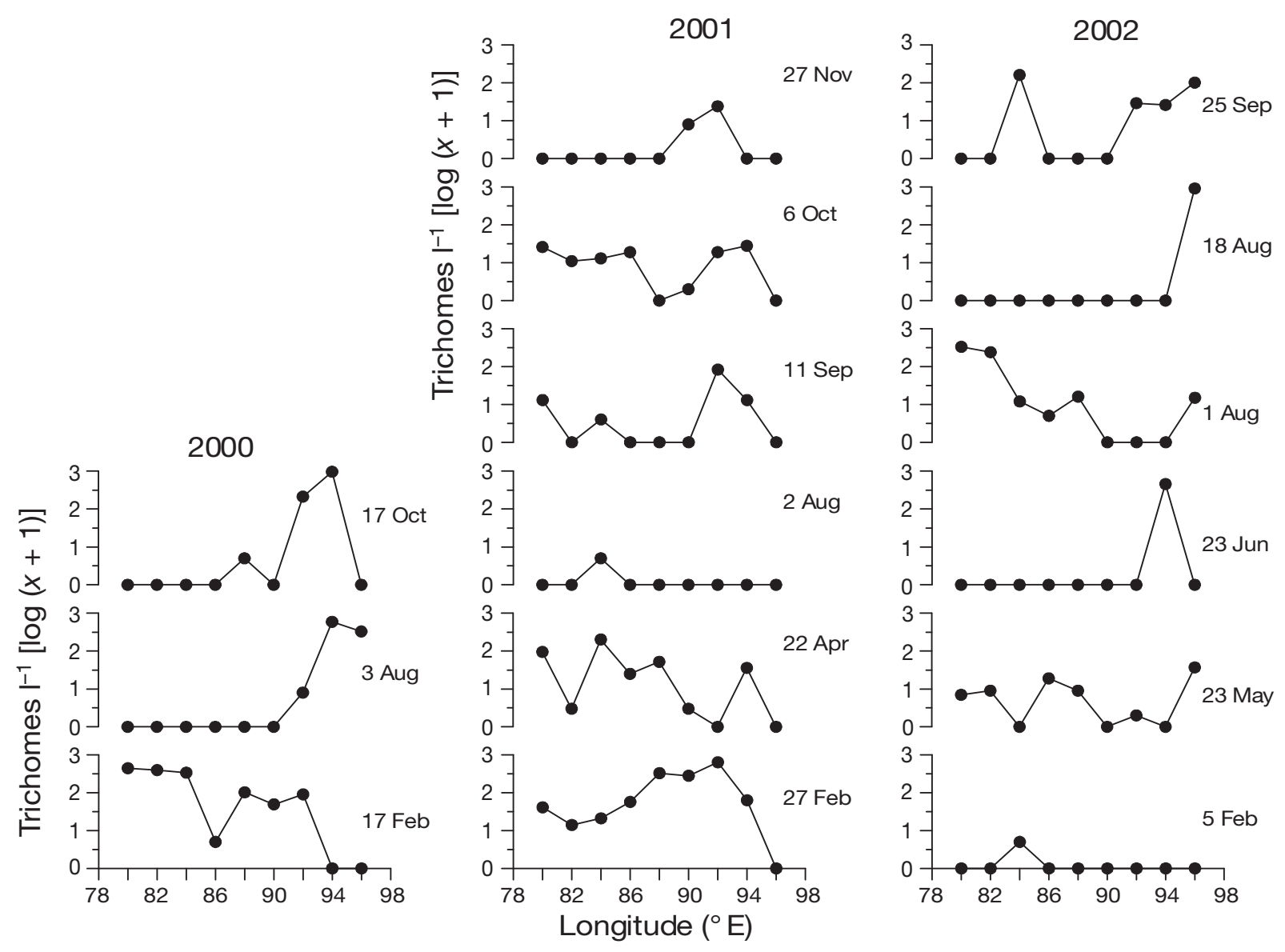

Fig. 2. Trichodesmium spp. abundance (trichomes $\mathrm{l}^{-1}$ ) plotted for the ship-based observations in the 15 transects between Chennai and Singapore, with longitude on the $x$-axis and number of individual filaments (trichomes) on the $y$-axis

remote sensed data, 3 more locations with no occurrence of Trichodesmium were randomly selected (February 5, 2002 at $12.99^{\circ} \mathrm{N}, 81.06^{\circ} \mathrm{E}$, October 6, 2001 at $11.51^{\circ} \mathrm{N}, 86.19^{\circ} \mathrm{E}$ and August 2, 2001 at $9.46^{\circ} \mathrm{N}$, $92.84^{\circ} \mathrm{E}$; Fig. 2) and were checked against remotely sensed images. These points, too, matched positively with remotely sensed images. Hence, we assume that the flag can be used to determine presence of Trichodesmium in the Bay. Trichodesmium was recorded in the Bay ( 4 to 100 trichomes $\mathrm{l}^{-1}$ ) in most transects. Using the ship-based observation as starting points, we further explored the temporal and spatial variations of Trichodesmium using remote sensing for the period 1997 to 2003.

Occurrence of Trichodesmium is predominant in the Bay of Bengal especially in the winter months (November to January, Fig. 3a-f). During summer (February to May, Fig. 3g-1), the occurrence of Trichodesmium is nearer to the east coast of India and in the eastern Arabian Sea. However, in the Arabian Sea the incidences of Trichodesmium are comparatively fewer than in the Bay. Trichodesmium occurrences increased over the years in the winter months from 1998-2001, followed by a decrease in 2001-2002, after which it again increased in 2002-2003. The period 1997-2003 covers 2 El Niño events: 1997-1998 and 2002-2003. Fig. 3a shows minimal spots for Trichodesmium in November 1997 to January 1998. It should be noted that numbers of images for this period were few and coverage was nil for the Bay of Bengal (however, October data, not shown, indicated the presence of Trichodesmium). November 2002 to January 2003 (Fig. 3f) showed a widespread occurrence of Trichodesmium in the south central part of the Bay, spreading to the east and west coast in the subsequent months, with the highest occurrence noticed off the east coast of India. Data for February to May 1999 (Supplementary Materials Fig. A8) was different from the other years, with many occurrences of Trichodesmium in the Bay of Bengal.

\section{DISCUSSION}

The interesting and intriguing feature of Trichodesmium blooms is the suddenness with which the blooms appear and disappear (Qasim 1972). Devassy 

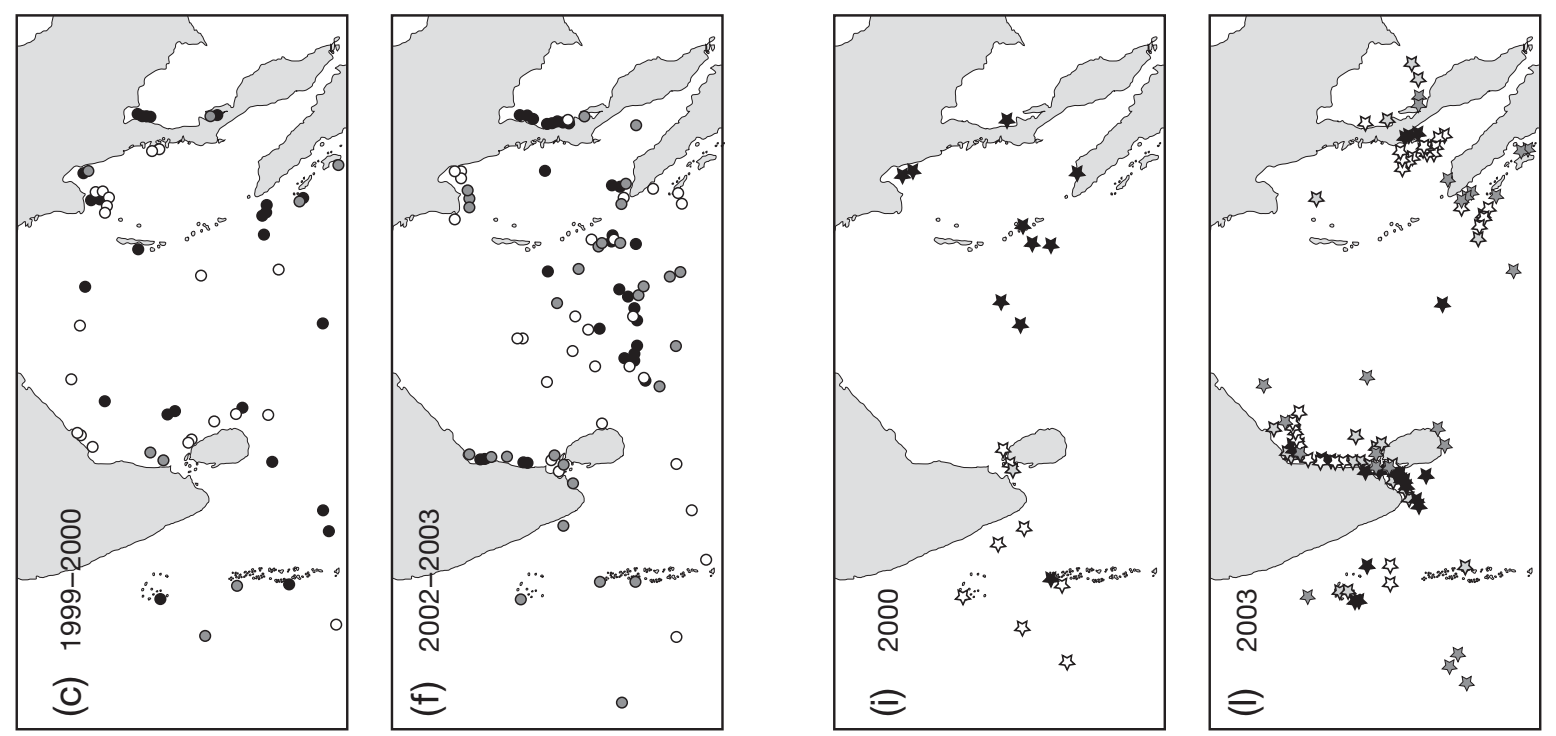

0
0
0
0
0
01
0
0
0
0
0
0
0
0
0
0
0
0
0
0
0
0
0
0
0
0
$z$
0
0
0
0
0
0
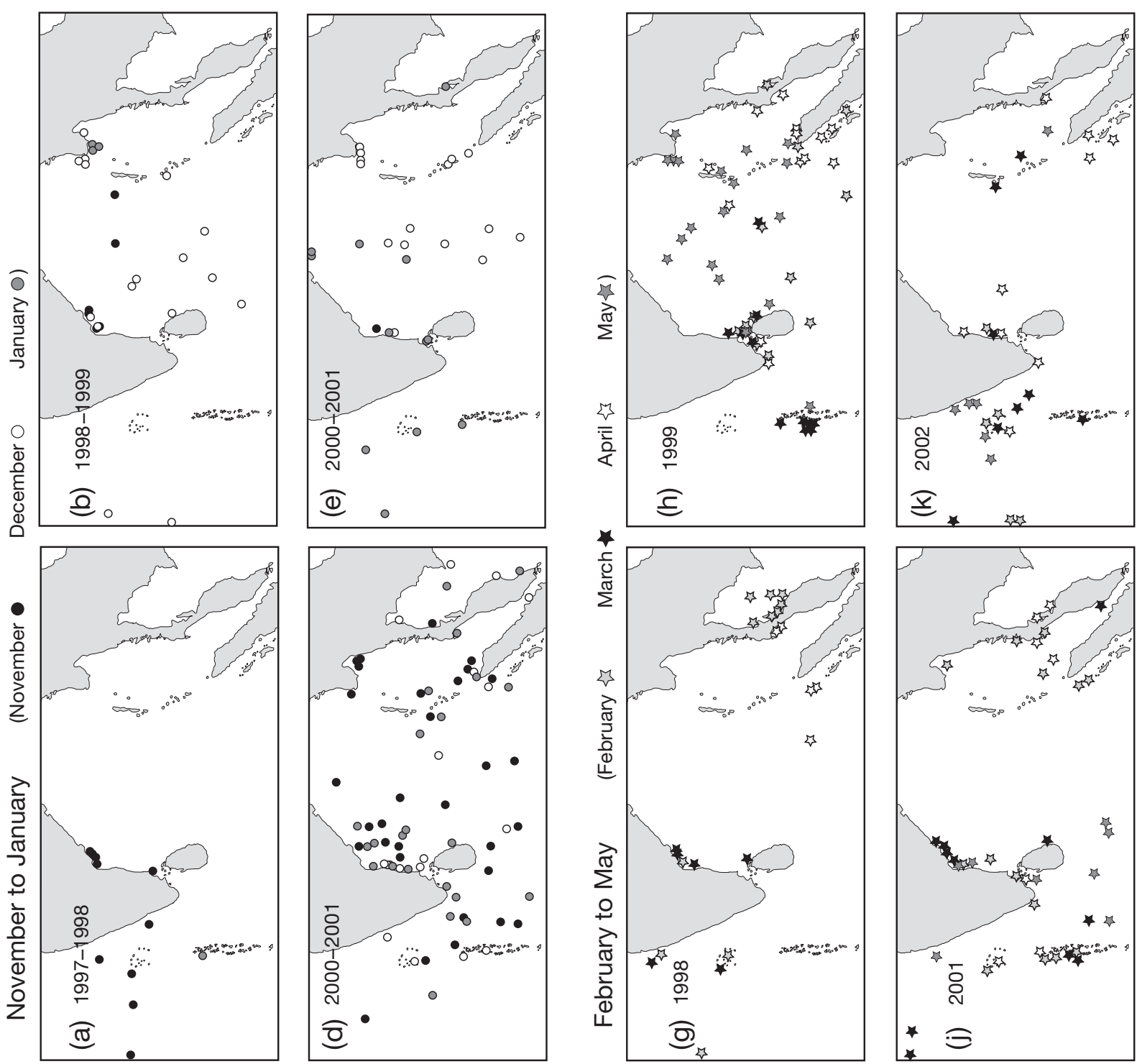

| 
et al. (1978) suggested 2 possibilities: Some kind of dormant resting stage may be present during nonbloom conditions which goes unnoticed or is misidentified during analyses; or, the organism in the nonbloom season remains distributed throughout the mixed-layer such that sampling at the surface under these conditions will show only a few filaments, and then, at the onset of favourable conditions the filaments become buoyant and come to the surface to form blooms. Recent observations using a video plankton recorder (Davis \& McGillicuddy 2006) revealed Trichodesmium colonies not just restricted to the surface but rather to a depth of as much as $130 \mathrm{~m}$.

Trichodesmium blooms have been observed on several occasions in the past in the area of our study (Ramamurthy et al. 1972, Devassy et al. 1978, Gomes et al. 2000, Jyothibabu et al. 2003). In the areas where we encountered high numbers of Trichodesmium, we sought the help of remote sensing to support our observation. Since our observations and the remotely sensed data matched fairly well, we also checked with the remotely sensed blooms reported by Jyothibabu et al. (2003) at $10^{\circ} 58^{\prime} \mathrm{N}, 81^{\circ} 50^{\prime} \mathrm{E}$ (Karaikal) on April 11, 2001 and at $19^{\circ} 44^{\prime} \mathrm{N}, 89^{\circ} 04^{\prime} \mathrm{E}$ (off Calcutta) on April 25, 2001. The former could not be seen in the remotely sensed images due to cloud cover (there were no cloud-free images for the entire week for the region). The latter was picked up by remote sensors and showed Trichodesmium patches close to the area at $20.07^{\circ}$ to $20.16^{\circ} \mathrm{N}, 86.95^{\circ}$ to $87.20^{\circ} \mathrm{E}$. Since the study region comes under the influence of monsoon (June to September), the retrieval of data through remote sensing was hampered due to cloud cover over the area. At such times, one has to rely on ground truth data to get a comprehensive view of Trichodesmium in the Bay of Bengal.

This study shows that Trichodesmium are abundant during the fall and winter in the Bay (Fig. 3a-f). Subsequently, they were encountered abundantly during the summer months along the coasts of India (Fig. 3g-l). An inter-annual variability in the distribution of Trichodesmium was observed. The remotely sensed images show the presence of Trichodesmium almost round the year in the south-eastern sector. The signatures of Trichodesmium from ship-based collections (Fig. 2) also indicate their prevalence in the south-eastern sector and show a west or north-westward propagation. From the ground data (Fig. 2), it appears that Trichodesmium originates and blooms in the southeast and then appears to move north westwards, forming blooms in the western Bay of Bengal after a few months. Remotely sensed images also suggest that Trichodesmium generally proliferates in the southeastern part of the Bay during the winter months and in the west (west Bay of Bengal and east Arabian Sea) during summer.
Resting cells in phytoplankton are a well-known biological strategy to survive adverse conditions. Such a strategy is not well reported with Trichodesmium. In light of this, seeding of a new bloom will have to be dependent on the residual survivors of the previous bloom at very low densities. Berman-Frank et al. (2004) speculated that programmed cell death pathways in Trichodesmium may regulate differentiation of selected cells into hormogonia (small group of cells that are released from a parent filament after death), providing an inocula for the new bloom upon improved environmental conditions. It was also stated that hormogonia are observed in a typically deep position in the euphotic zone around or below $1 \%$ light level after large fraction of trichomes decomposed. This highlights the possibility that hydrographic settings may play an important role in seeding as well as in its distribution. In order to elucidate the reasons for the prevalence of Trichodesmium in the Bay, we have looked into the hydrographic settings of the Bay of Bengal, i.e. temperature (SST), mixed layer depth and stratification, nutrient availability, and currents.

\section{Temperature}

There was no correlation between temperature and the abundance of Trichodesmium in this study. This may be attributed to the temperature range in the study region $\left(27^{\circ}\right.$ to $\left.32^{\circ} \mathrm{C}\right)$ being well within the favoured range for its growth. Tyrrell et al. (2003) also found a lack of correlation between temperature and Trichodesmium for the Atlantic Ocean.

\section{Shallow mixed layer depth and stratification of the water column}

Abundance of Trichodesmium was found to correlate with shallow mixed layer depths (Tyrrell et al. 2003) and the Bay of Bengal has a shallow mixed layer depth of $\sim 30 \mathrm{~m}$ (Prasad 2004). The seasonal cycle of the barrier layer is computed up to $25 \mathrm{~m}$ in the Bay of Bengal and eastern equatorial Indian Ocean in winter (de Boyer Montégut et al. 2004). The other aspect necessary for the growth of Trichodesmium is stratification, as this allows the cells to float to the surface (Carpenter \& Price 1976). The predominance of Trichodesmium blooms during February to May along the west coast of India is also attributed to stratification (Devassy et al. 1978). The Bay of Bengal shows stratification of water almost throughout the year due to the variations in the salinity brought about by fresh water influx (Shetye et al. 1993). Even the cold continental winds of the Northeast Monsoon does not cool the sur- 
face water enough to cause an inversion since the overturning is prevented or reduced by the stable background stratification due to strong salinity gradients (Tomczak \& Godfrey 1994).

\section{Nutrient availability}

It is well known that Trichodesmium is generally seen in nutrient poor waters. Iron and phosphorous limitation are most often suspected to affect the growth of Trichodesmium (Karl et al. 1992, Rueter et al. 1992). Low surface $\mathrm{PO}_{4}{ }^{3-}$-P values of $0.1 \mu \mathrm{g}$-at $\mathrm{l}^{-1}$ have been recorded in the Bay of Bengal and Andaman sea increasing to a maximum of $2.90 \mu \mathrm{g}$-at $\mathrm{l}^{-1}$ at depth (Kabanova 1964, Rozanov 1964). Likewise, the dissolved nitrate and nitrite values in the Bay of Bengal are also reported to be low in the surface waters and increase sharply to $15-20 \mu \mathrm{g}$-at $\mathrm{l}^{-1}$ in the thermocline and up to $26 \mu \mathrm{g}$-at $\mathrm{I}^{-1}$ at depth (Kabanova 1964, Rozanov 1964). The dominance of the Trichodesmium in the Bay of Bengal and the reported low concentration of $\mathrm{PO}_{4}$ indicate the potential importance of the mechanisms such as phosphorus mining (Karl et al. 1992). Mullholland et al. (2002) report that organic phosphate alleviated $\mathrm{P}$ limitation and promoted $\mathrm{P}$ uptake and growth. In this context it is worthwhile to note that the Bay of Bengal has a higher level of organic phosphate in the surface waters when compared to inorganic phosphate (Rao \& Rao 1968). Iron has been implicated to be a limiting factor for Trichodesmium growth. High iron deposition to the surface ocean correlated to high abundance of Trichodesmium (Tyrrell et al. 2003). The aerosol input from the subcontinent carrying iron dust might have a role to play in the proliferation of the organism. While the Arabian Sea receives more atmospheric input of crustal dust containing non-sea sulfate, nitrate, phosphate and iron from the Arabian Desert (Patra et al. 2007), the Bay of Bengal receives aerosols due to anthropogenic activities (D. Kumar pers. comm.). Iron from the pollution sources produce labile forms of Fe (Siefert et al. 1999) and this bio-available Fe may be utilized by Trichodesmium. Thus, the amount of bio-available iron in the 2 basins might determine the proliferation of Trichodesmium.

The El Niño years (2002-2003) showed the widespread occurrence of Trichodesmium (Fig. 3f). A rough correspondence between the strength of the Southern Oscillation Index (SOI) and the occurrence of Trichodesmium blooms (where positive excursions in the SOI correspond to the greater aerial extent of Trichodesmium blooms) was found (Westberry \& Siegel 2006). Although there were no satellite images for November 1997 to January 1998, the SeaWiFS Level 3 images show high chlorophyll concentration (Supplementary Materials Fig. A1) in the south-eastern sector. In this context, Abram et al. (2003) reported high iron discharge into the sea as a result of the Indonesian forest fires. They also reported the occurrence of a red tide spreading over hundreds of kilometers, which caused the death of coral reefs. There is no evidence as to the identity of the bloom organism, and the bloom was thought to be caused by dinoflagellates. Based on the literature, it could have been a Trichodesmium bloom as it is well known that Trichodesmium is capable of forming red tides which spread over hundreds of kilometers, and they are also responsible for the smothering of corals (Bell et al. 1999). In the subsequent El Niño year (November 2002 to January 2003, Fig. 3f), Trichodesmium was seen in the Bay of Bengal as well as along the coast of India.

\section{Currents}

Currents seem to play an important role in the dispersal of Trichodesmium in the Indian Ocean. Ship drifts in the Bay of Bengal based on $10 \mathrm{~d}$ averages compiled by Cutler \& Swallow (1984) show a westward movement of the North Equatorial Current (NEC) from December to March. The NEC is described as a narrow current with a speed of about $0.3 \mathrm{~m} \mathrm{~s}^{-1}$ running from the Malacca Strait to southern Sri Lanka (Tomczak \& Godfrey 2003). Those authors further elaborate on the evolution of surface currents through the seasons, showing that the NEC is prominent in March to April. Between September and November the direction of the East India Coastal Current (EICC) is equator-ward (Shetye et al. 1996) along the east coast of India. This current turns northwards south of Sri Lanka and flows into the Arabian Sea (Tomczak \& Godfrey 2003). Remote-sensed observations (Dupuoy et al. 2000) show high abundance of Trichodesmium in the south-west pacific as a recurring phenomenon. Considering the Indonesian throughflow (Gordon 2001), it is possible to deduce dispersion of trichomes westward by currents causing seeding between December and February, resulting in blooms off the west coast of India between February and May. During November 2002, extensive blooms were reported off the coast of south-east Queensland, Australia (Bell et al. 2005) and the signatures were also seen in the eastern sector of the study area (Fig. 3f) and spread westwards. Davis \& McGillicuddy (2006) observed higher abundance of Trichodesmium in the anticyclonic eddies and attributed this covariance to eddydriven transport of these populations from a distant source region, indicating that Trichodesmium dispersal is current-driven. 
It was also initially opined that colonies can be destroyed by strong winds (Capone et al. 1997). However, Davis \& McGillicuddy (2006) found no reduction in colony abundance in a region affected by hurricanes (wind speed $200 \mathrm{~km} \mathrm{~h}^{-1}$ ). In view of this, it is possible that Trichodesmium can survive in the Bay of Bengal, which is cyclone-ridden during the north-east monsoons. It can be deduced that the Bay of Bengal is conducive for Trichodesmium blooms due to its unique hydrography. Further studies to elucidate this phenomenon with rigorous sampling coupled with remote sensing and video profiling of the water column will be of immense use in understanding the biogeochemistry of the area.

Acknowledgements. The initiation of this work related to phytoplankton ecology through the Indian XBT programme is solely due to the visionary planning by Dr. A. B. Wagh. He passed away recently and this work is dedicated to him. A.C.A., V.K. and V.V.G. wish to place on record their indebtedness to the encouragement received. The authors are grateful to the Director of the National Institute of Oceanography (NIO) and the colleagues of the Marine Corrosion and Materials Research Division (MCMRD) for their support. The Nippon Foundation and the Partnership for the Observations of the Global Oceans (POGO) are duly thanked for the training course on remote sensing in Kochi, India. Dr. Shubha Sathyendranath (Bedford Institute of Oceanography, Canada), Dr. M. Dileep Kumar and Dr. T. Pankajakshan from NIO are thanked for their valuable insights and encouragement. Mr. Gourish Salgaonkar, Ms. Nisha Kurian, Mr. Nagesh Bhatkar and Mr. Vinayak Kulkarni are thanked for their contribution. Phytoplankton samples were collected with the help of the team from the Indian XBT programme funded by the Department of Ocean Development and their co-operation is acknowledged. This is NIO contribution number (4345).

\section{LITERATURE CITED}

Abram NJ, Gagan MK, McCulloch MT, Chappell J, Hantoro WS (2003) Coral reef death during the 1997 Indian Ocean dipole linked to Indonesian wildfires. Science 301: 952-955

Bell PRF, Elmetri I, Uwins P (1999) Nitrogen fixation of Trichodesmium spp. in the Central and Northern Great Barrier Reef Lagoon: relative importance of the fixed-nitrogen load. Mar Ecol Prog Ser 186:119-126

Bell PRF, Uwins PJR, Elmetri I, Phillips JA, Fu F, Yago AJE (2005) Laboratory culture studies of Trichodesmium isolated from the Great Barrier Reef Lagoon, Australia. Hydrobiology 532:9-21

Berman-Frank I, Bidle KD, Harmaty L, Falkowski PG (2004) The demise of the marine cyanobacterium, Trichodesmium spp., via an autocatalyzed cell death pathway. Limnol Oceanogr 49:997-1005

Borstad GA, Gower JFR, Carpenter EJ (1992) Development of algorithms for remote sensing of Trichodesmium blooms. In: Carpenter EJ, Capone DG, Reuter JG (eds) Marine pelagic cyanobacteria: Trichodesmium and other diazotrophs. Kluwer Academic Publishers, Dordrecht, p 193-210

Capone DG, Subramaniam A (2005) Seeing microbes from space. Am Soc Microbiol News 71:179-186
Capone DG, Zehr JP, Paerl HW, Carpenter EJ (1997) Trichodesmium, a significant marine cyanobacterium. Science 276:1221-1229

Capone DG, Subramaniam A, Montoya JP, Voss M, Humborg C, Johansen AM, Siefert RL (1998) An extensive bloom of the $\mathrm{N}_{2}$-fixing cyanobacterium Trichodesmium erythraeum in the central Arabian Sea. Mar Ecol Prog Ser 172: 281-292

Carpenter EJ, Price CC (1976) Marine Oscillatoria (Trichodesmium): explanation for aerobic nitrogen fixation without heterocysts. Science 191:1278-1280

Carpenter EJ, Capone DG, Fry B, Harvey HR (1997) Biogeochemical tracers of the marine cyanobacterium Trichodesmium. Deep-Sea Res I 44:27-38

Cutler AN, Swallow JC (1984) Surface currents of the Indian Ocean (to $25^{\circ} \mathrm{S}, 100^{\circ} \mathrm{E}$ ): compiled from historical data archived by the Meteorological Office, Bracknell, UK, Rep. 187. Institute of Oceanographic Sciences, Wormley

Davis CD, McGillicuddy DJ Jr (2006) Transatlantic abundance of the $\mathrm{N}_{2}$-fixing colonial cyanobacterium Trichodesmium. Science 312:1517-1520

de Boyer Montégut C, Fischer AS, Lazar A, Iudicone D, Madec G (2004) A global mixed layer depth climatology based on individual profiles. Geophysical Res Abs 6:02726

Devassy VP, Bhattathiri PMA, Qasim SZ (1978) Trichodesmium phenomenon. Ind J Mar Sci 7:168-186

Dupuoy C, Neveux A, Subramaniam MR, Mulholland MR, Montoya JP, Campbell L, Capone DG, Carpenter EJ (2000) Satellite captures Trichodesmium blooms in the Southwestern Tropical Pacific. EOS 81:13-16

Gomes HR, Goes IJ, Saino T (2000) Influence of physical processes and freshwater discharge on the seasonality of phytoplankton regime in the Bay of Bengal. Cont Shelf Res 20:313-330

Gordon AL (2001) Interocean exchange. In: Sidler G, Church J, Gould J (eds) Ocean circulation and climate: observing and modelling the global ocean. International Geophysics Series, Vol 77. Academic Press, San Diego, CA, p 303-314

Jyothibabu R, Madhu NV, Murukesh N, Haridas PC, Nair KKC, Venugopal P (2003) Intense blooms of Trichodesmium erythraeum (Cyanophyta) in the open waters along the east coast of India. Indian J Mar Sci 32:165-167

Kabanova JG (1964) Primary production and nutrient salt content in the Indian Ocean waters in October to April 1960/61. Tr Inst Okeanol Akad Nauk SSSR 64:85-93

Karl DM, Letelier R, Hebel DV, Bird DF, Winn CD (1992) Trichodesmium blooms and new nitrogen in the North Pacific Gyre. In: Carpenter EJ, Capone DG, Rueter JG (eds) Marine pelagic cyanobacteria: Trichodesmium and other diazotrophs. Kluwer Academic Publishers, Dordrecht, p 219-237

> Mulholland MR, Floge S, Carpenter EJ, Capone DG (2002) Phosphorus dynamics in cultures and natural populations of Trichodesmium spp. Mar Ecol Prog Ser 239:45-55

Patra PK, Kumar MD, Mahowald N, Sarma VVSS (2007) Atmospheric deposition and surface stratification as controls of contrasting chlorophyll abundance in the North Indian Ocean. J Geophys Res 112:C05029, doi: 10.1029/ 2006JC003885

Prasad TG (2004) A comparison of mixed-layer dynamics between the Arabian Sea and Bay of Bengal: one-dimensional model results. J Geophys Res 109:C03035, doi: 10.1059/2003JC002000

Qasim SZ (1972) Some observations on Trichodesmium blooms. In: Desikachary TV (ed) Proceedings of the symposium on taxonomy biology of blue-green algae. Bangalore Press, Bangalore, p 433-438 
Ramamurthy VD, Selvakumar A, Bhargava RMS (1972) Studies on the blooms of Trichodesmium erythraeum (Ehr) in the waters of the central West coast of India. Curr Sci 41:803-805

Rao VC, Rao TSS (1968) Distribution of total phosphorous in the Bay of Bengal. Bull Natl Inst Sci India 38:93-102

Rozanov AG (1964) Distribution of phosphate and silicate in the waters of the northern part of the Indian Ocean. Tr Inst Okeanol Akad Nauk SSSR 64:102-114

Rueter JG, Hutchins DA, Smith RW, Unsworth NL (1992) Iron nutrition of Trichodesmium. In: Carpenter, EJ, Capone DG, Rueter JG (eds) Marine pelagic cyanobacteria: Trichodesmium and other diazotrophs. Kluwer Academic Publishers, Dordrecht, p 289-306

Sathyendranath S, Gouveia AD, Shetye SR, Ravindran P, Platt $T$ (1991) Biological control of surface temperature in the Arabian Sea. Nature 349:54-56

Shetye SR, Gouveia AD, Shenoi SSC, Sundar D, Michael GS, Nampoothiri G (1993) The Western boundary current of the seasonal subtropical gyre in the Bay of Bengal. J Geophys Res 98(C1):945-954

Shetye SR, Gouveia AD, Shankar D, Shenoi SSC and others (1996) Hydrography and circulation in the western Bay of Bengal during the northeast monsoon. J Geophys Res 101(C6):14011-14025

Siefert R, Johansen AM, Hoffmann MR (1999) Chemical char-

Editorial responsibility: Matthias Seaman,

Oldendorf/Luhe, Germany acterization of ambient aerosol collected during the southwest monsoon and intermonsoon seasons over the Arabian Sea: labile-Fe (II) and other trace metals. J Geophys Res 104:3511-3526

Subramaniam A, Brown CW, Hood RR, Carpenter EJ, Capone DG (2001) Detecting Trichodesmium blooms in SeaWiFS imagery. Deep-Sea Res II 49(1):107-121

Tassan S (1995) SeaWiFS potential for remote sensing of marine Trichodesmium spp. at sub-bloom concentration. Int J Remote Sens 16:3619-3627

Tomczak M, Godfrey JS (1994) Regional oceanography: an introduction. Pergamon, Oxford

Tomczak M, Godfrey JS (2003) Regional oceanography: an introduction, 2nd edn. Available at: www.es.flinders.edu.au/ $\sim$ mattom/regoc/pdfversion.html

Tyrrell T, Maranson E, Poulton AJ, Bowie AR, Harbour DS, Malcolm E, Woodward S (2003) Large-scale latitudinal distribution of Trichodesmium spp. in the Atlantic ocean. J Plankton Res 25:405-416

Westberry TK, Siegel DA (2006) Spatial and temporal distribution of Trichodesmium blooms in the world's oceans. Global Biogeochem Cycles 20:GB4016

Westberry TK, Siegel DA, Subramaniam A (2005) An improved bio-optical model for the remote sensing of Trichodesmium spp. blooms. J Geophys Res 110:C06012, doi: 10.1029/2004JC002517

Submitted: March 14, 2007; Accepted: September 20, 2007

Proofs received from author(s): February 18, 2008 